\title{
九州歯科大学における OSCEトライアルの評価
}

\begin{tabular}{|c|c|c|c|c|c|c|c|c|c|c|}
\hline 有 & 田 & 正 & 博 & - 西 & 田 & 郁 & 子 & - 吉 & 野 & 賢 \\
\hline 中 & 村 & 恵 & 子 & - 小 & 城 & 辰 & 郎 & - 北 & 村 & 知 \\
\hline 木 & 尾 & 哲 & 朗 & - 大 & 住 & 伴 & 子 & - 坂 & 本 & 英 \\
\hline 庄 & 野 & 庸 & 雄 & - 黒 & 川 & 英 & 雄 & - 安 & 細 & 敏 \\
\hline & 田 & 利 & 道 & - 佐 & 藤 & 耕 & 一 & • 篠 & 原 & 雄 \\
\hline & 田 & 祐 & 司 & - 園 & 木 & 一 & 男 & - 芳 & 賀 & 健 \\
\hline 木 & 田 & 貴 & 俊 & - 林 & 田 & & 裕 & • 横 & 田 & \\
\hline & 下 & 正 & 道 & - 西 & 原 & 達 & 次 & & & \\
\hline
\end{tabular}

九州歯科大学 OSCE 実行委員会

平成 16 年 10 月 20 日受付

平成 16 年 12 月 16 日受理

Evaluation of the OSCE Trial in Kyushu Dental College

Masahiro Arita, Ikuko Nishida, Kenichi Yoshino,

Keiko Nakamura, Tatsuro Kojo, Chiaki Kitamura,

Tetsuro Konoo, Tomoko Ohsumi, Eiji Sakamoto,

Yasuo Shono, Hideo Kurokawa, Toshihiro Ansai,

Toshimichi Ichida, Koichi Satoh, Yuji Shinohara,

Yuji Seta, Kazuo Sonoki, Kensuke Haga,

Takatoshi Murata, Yutaka Hayashida, Makoto Yokota,

Masamichi Terashita and Tatsuji Nishihara

OSCE Executive Committee, Kyushu Dental College

The OSCE Trials at Kyushu Dental College for 86 and 94 of fifth year students were individually performed on March 15 and December 6, 2003. The first trial consisted of 5 stations (medical interview, instruction of tooth brushing, rubberdam dry field technique, alginate impression technique, tooth extraction). The second trial consisted of 7 stations (medical interview, dental X-ray film mount, filling of composite resin, root canal treatment, tooth preparation, explanation of the orthodontic appliance, check the vital sign). The average score was 79.4 point in the first and 80.4 point in the second trails, respectively. The average score in clinical skill was lower than that in the medical interview and explanation of the orthodontic appliance. Also, the average score in clinical skill was affected by place and the order of the examination.

Key words: OSCE Trial/Objective Structured Clinical Examination/Kyushu Dental College 


\section{緒}

共用試験歯学 OSCE (Objective Structured Clinical Examination）は, 平成 17 年度の本格実施に向け て,これまで各歯科大学においてトライアルが行われ， トライアルの内容や OSCEに関連した研究が報告され ている1-12). 本学においても，2002 年 7 月に OSCE 実行 委員会を立ち上げ，学内ワークショップや臨床研修医を 対象としたOSCE を実施したのち，2003 年 3 月 15 日に 平成 14 年度 OSCE トライアル（第 1 回）を, 2003 年 12 月 6 日に平成 15 年度 OSCE トライアル（第 2 回）を実 施した.

OSCEトライアルの実施や各地で実施される OSCE などの歯学教育に関連するワークショップへの参加，さ らに外部評価者の経験や学内での FD 講演会を通して, 本学の多くの教員が，OSCE について理解し，その意義 を認めている，さらに，OSCEというひとつの評価方法 を知ることにより，これまでの講義や実習内容を検討す る講座も増加してきた。

そこで, 今後の本学に㧍ける歯学教育のあり方を検討 する上での資料とするため，第 1 回抢よび第 2 回の OSCEトライアルにおける実施結果について検討を行っ た.

\section{方法}

\section{1. 実施対象}

平成 14 年度抒よび 15 年度九州歯科大学 5 年次生 $(89$ 名および 99 名）を対象とした。実施時期は，約 1 か月間
の予備登院実習が終了し, 本登院開始直後であった.

2. 実施課題扔よび模擬患者

課題およびステーション運営の担当講座を表 1 に示 す. 課題は分科会加ら提示されているコア課題から選択 した. 平成 14 年度は 5 課題（普通抜歯，ブラッシング指 導, ラバーダム防湿, 概形印象採得, 急性期の初診患者 の医療面接), 平成 15 年度は 7 課題（慢性期の初診患者 の医療面接, エックス線フィルムの整理と読影, レジン 充填, 根管治療, 支台歯形成, 矯正装置の説明, バイ夕 ルサイン)とした。課題文・評価シート・評価基準の作成 およびステーションの運営は, 複数の関連講座の実行委 員が中心之なり講座間で協力して行った。面接·指導系 課題の模擬患者は学内で養成した。

3. 実施方法

1) 試験方法

課題提示 1 分, 試験 5 分, フィードバック 1 分, 移動 30 秒（1 回目）または 1 分（2 回目）とした。フィード バックは 1 名の評価者が試験直後に行った。試験は ショットガン方式で， 3 列で実施した。これを時間差で 3 および 4 回繰り返した。技術系課題ではグローブの着 用を義務づけた。

\section{2）試験会場}

第 1 回は, 九州歯科大学附属病院 6 階の口腔外科之有 病者歯科の診療室に，それぞれ 2列（A列，B列）亡 1 列 (C列) でステーションをレイアウトした. 第 2 回は, 6 階の口腔外科の診療室 (A列), 5 階の義歯科 (B 列), 4 階の総合歯科（C列）に，それぞれ1列のステーショ ンレイアウトを行った.

表 1 年度別ステーション課題と担当講座

\begin{tabular}{|c|c|c|}
\hline 年度 & 課題 & 担当講座 \\
\hline 14 年度 & $\begin{array}{l}\text { 普通抜歯 } \\
\text { ラバーダム防湿 } \\
\text { ブラッシング指導 } \\
\text { 概形印象採得 } \\
\text { 医療面接（急性期） }\end{array}$ & $\begin{array}{l}\text { 口外 } 1 \cdot \text { 口外 } 2 \\
\text { 小児歯 } \cdot \text { 保存 } 1 \\
\text { 保存 } 2 \cdot \text { 予防歯 } \\
\text { 補綴 } 1 \cdot \text { 補綴 } 2 \cdot \text { 歯矯正 } \\
\text { 歯放線 } \cdot \text { 歯麻酔 } \cdot \text { 内科·外科 } \cdot \text { 総合柬 }\end{array}$ \\
\hline 15年度 & $\begin{array}{l}\text { 医療面接（慢性期） } \\
\text { エックス線フィルムの整理と読影 } \\
\text { レジン充填 } \\
\text { 根管治療 } \\
\text { 支台歯形成 } \\
\text { 矯正装置の説明 } \\
\text { バイタルサイン }\end{array}$ & $\begin{array}{l}\text { 予防歯 } \cdot \text { 内科 } \cdot \text { 外科 } \\
\text { 歯放線·口外 } 1 \\
\text { 保存 } 1 \cdot \text { 総合歯 } \\
\text { 保存 } 2 \cdot \text { 総合歯 } \\
\text { 補経 } 1 \cdot \text { 補経 } 2 \\
\text { 歯矯正·小坚歯 } \\
\text { 歯麻酔. 口外 } 2 \cdot \text { 外科 }\end{array}$ \\
\hline
\end{tabular}




\section{3) 受験生に対する事前説明と予備実習}

1 回目は, 本学に扔ける初めての本格 OSCEトライア ルであったため, 運営をスムースに行うため, 十分な事 前説明を行った。すなわち, OSCEについての一般説明 を行い, 試験課題む明らかにした。 各課題における一般 目標と到達目標を提示し, 評価項目之評価方法を説明し た。評価シート自体は提示しなかった５つの試験課題 については，予備登院実習において評価項目に準じた内 容で，できるだけ再教育を行った．

2 回目のトライアルでは, OSCEについての一般説明 を行い, 全コア課題について一般目標と到達目標, 評価 方法を説明した．医療面接については, 試験前日に外部 講師による集中講義を行った。 2 回目は試験課題を明ら かにせず，医療面接以外の課題に関する特別な再指導は 行わなかった。

\section{4) 試験結果の集計}

評価シートを回収し，各ステーションでのスコアを合 計した. 記入漏れ, 判別困難な場合は満点として集計し た。 2 名の評価者のスコアの平均值を算出し，スコアの 満点を 100 点としたときの値に換算して得点率（\%）を 求めた.

これらの結果について, 各年度の課題別平均得点率, 各課題における評価項目別得点率, 受験会場別得点率, 受験時間別得点率，判定基準に基づいた合否判定結果に ついてそれぞれ検討した。

\section{結 果}

\section{1. 受験者数}

平成 14 年度は 86 名 (欠席 3 名), 平成 15 年度は 94 名 （欠席 5 名）の 5 年次生にトライアルを実施した。

\section{2. 参加スタッフ}

平成 14 年度打よび平成 15 年度 OSCE 害施に参加し た人員とその内訳を図 1-a および図 1-bに示す. 本学に おいては分野に関わらず, 教授以下ほとんどすべての教 員が参加し, 模擬患者や運営担当として歯科衛生士や事 務職員の協力む得られた. 教職員に加え，平成 14 年度は 臨床研修医招よび大学院生が, 平成 15 年度は 4 年次生 と 3 年次生がスタッフとして参加した.

\section{3 。試験結果}

\section{1 ) 課題別平均得点率}

2 回のトライアルにおける課題別得点率の平均および 全課題の平均を図 2-a および 2-bに示す. 全課題の得点 率の平均は，1 回目が $79.4 \pm 8.0 \%$ （平均值土標準偏 差), 2 回目が $80.4 \pm 6.4 \%$ あっった. 課題別の得点率の

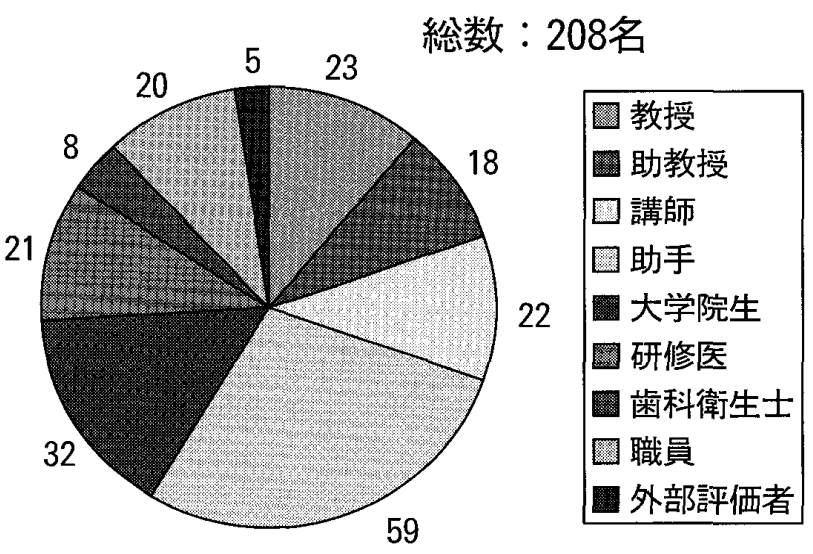

図 1-a 平成 14 年度トライアル参加者内訳.

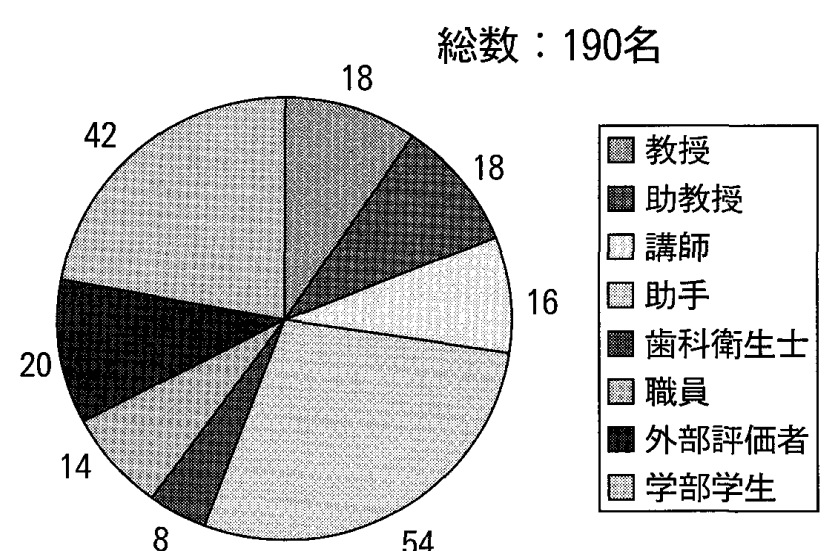

図 1-b 平成 15 年度トライアル参加者内訳.

平均值は, 面接·説明系課題に比較して技能系課題で低 くなる傾向が認められた。

2 ) 評価項目別得点率

第 1 回の課題別の各項目別得点率を図 3-a-e 示す. 第 2 回目の課題別の各項目別得点率を図 4-a-g に示す. 各 課題において, 得点の低かった評価項目を表 2 にまとめ た.

\section{3）受験会場別得点率}

各年度に括ける受験会場別平均得点率を図 5-a 打よ び図 5-bに示す。試験会場が同一フロアで, ステーショ ン設定やユニット仕様などが近似している 1 回目おいて は，列による平均得点率の差はほとんど認められなかっ た。試験会場を異なるフロアに設定した 2 回目において も，有意差は認められなかった。しかし，1回目と異な り 2 回目では, 診察·技能系課題のうち, レジン充填, 支 台歯形成，バイタルサインにおいて B 列（義歯科）での 得点率に低い傾向が認められた。一方, 面接·指導系課 


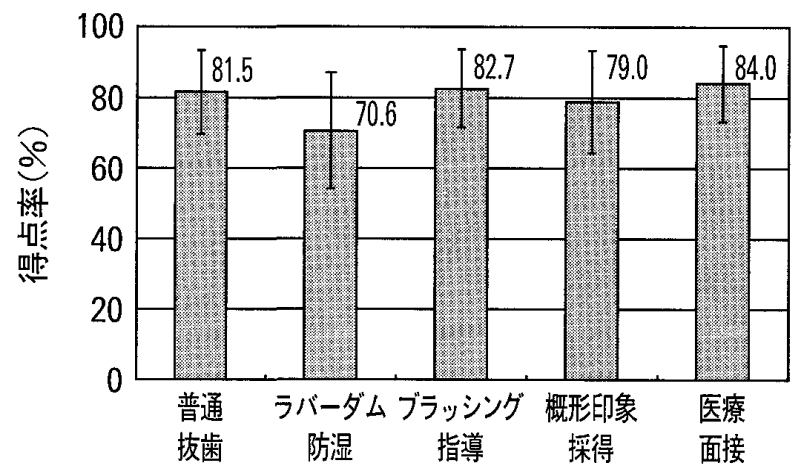

図 2-a 平成 14 年度トライアル 課題別得点率.

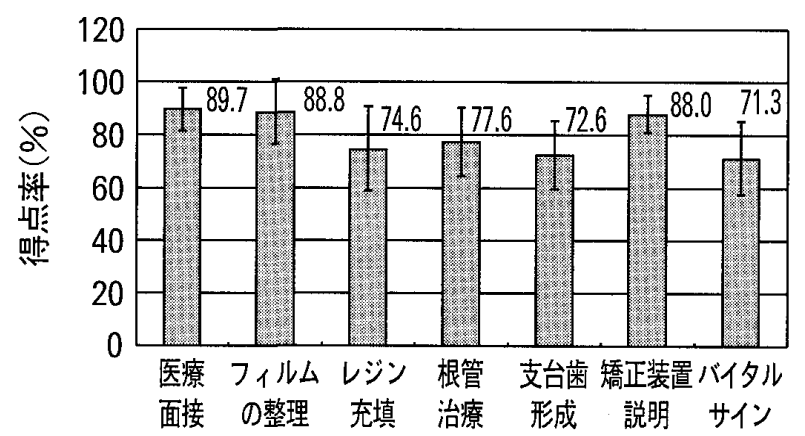

図 2-b 平成 15 年度トライアル 課題別得点率.

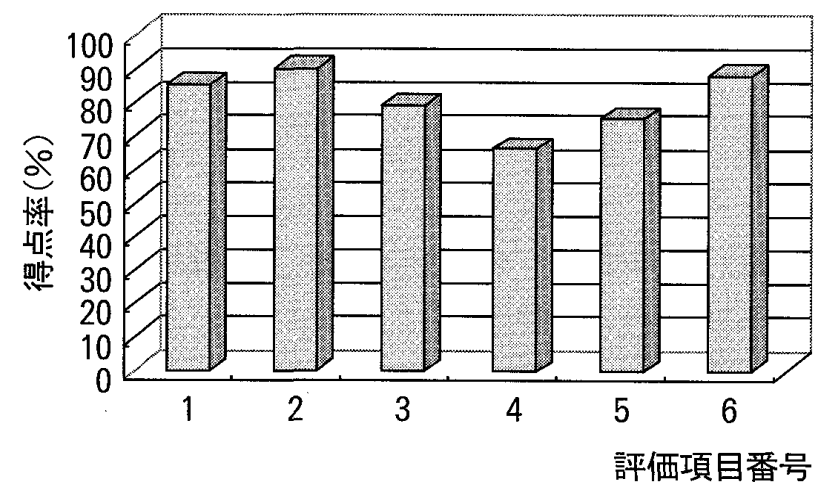

図 3-a 平成 14 年度評価項目別得点率 普通抜歯.

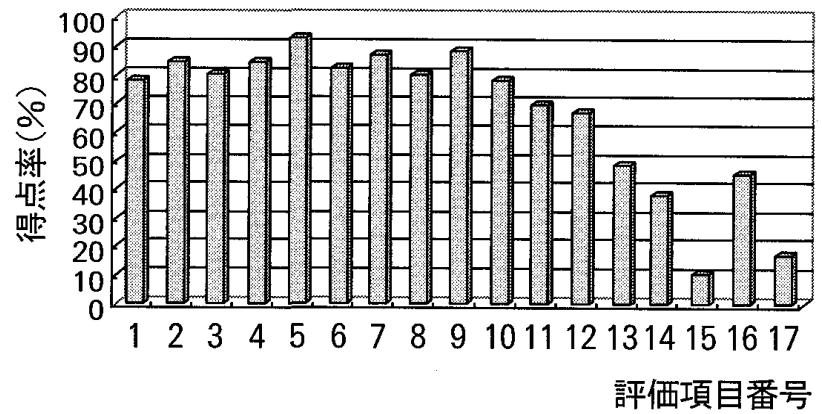

図 3-b 平成 14 年度評価項目別得点率 ラバーダム防湿.

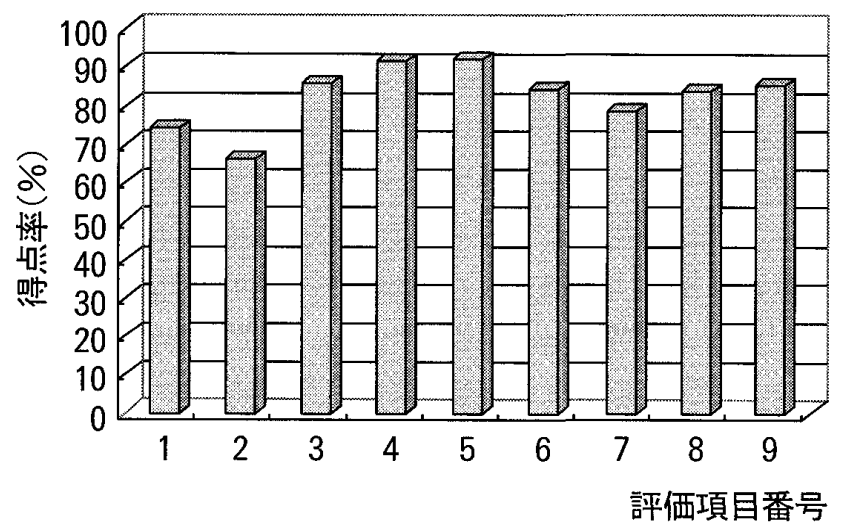

図 3-c 平成 14 年度評価項目別得点率 ブラッシング指導.

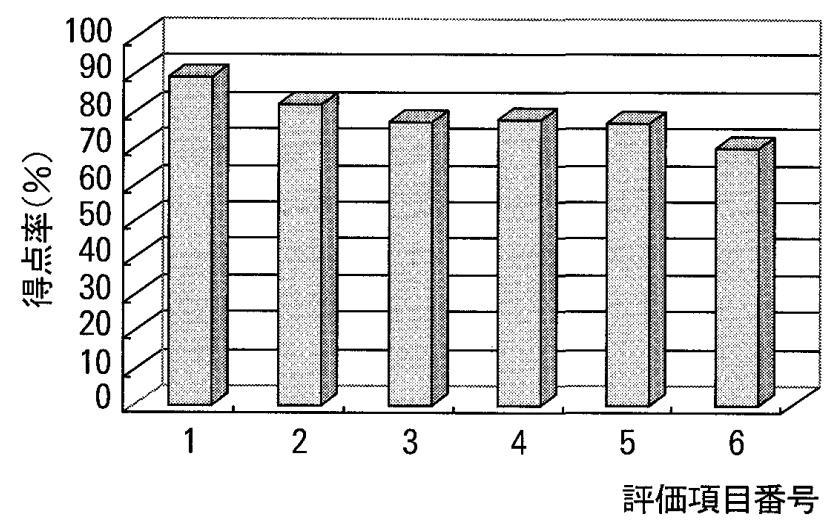

図 3-d 平成 14 年度評価項目別得点率 概形印象採得.

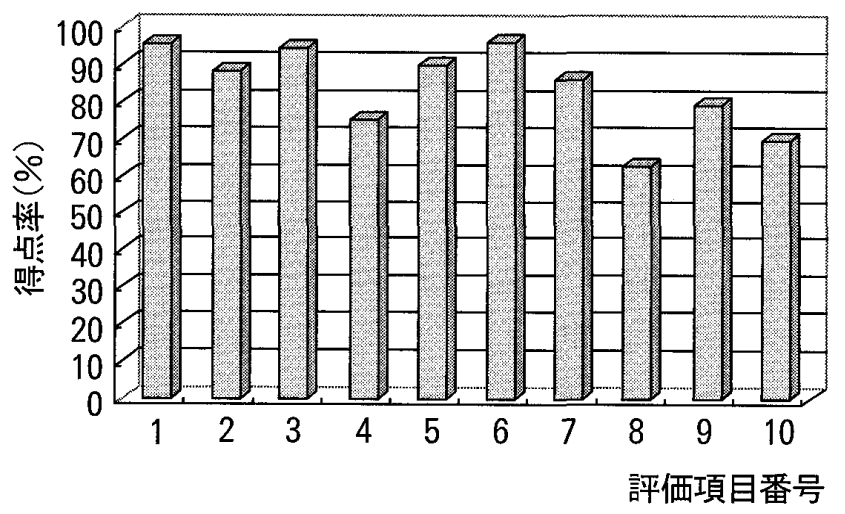

図 3-e 平成 14 年度評価項目別得点率 急性期の初診患者の医 療面接. 


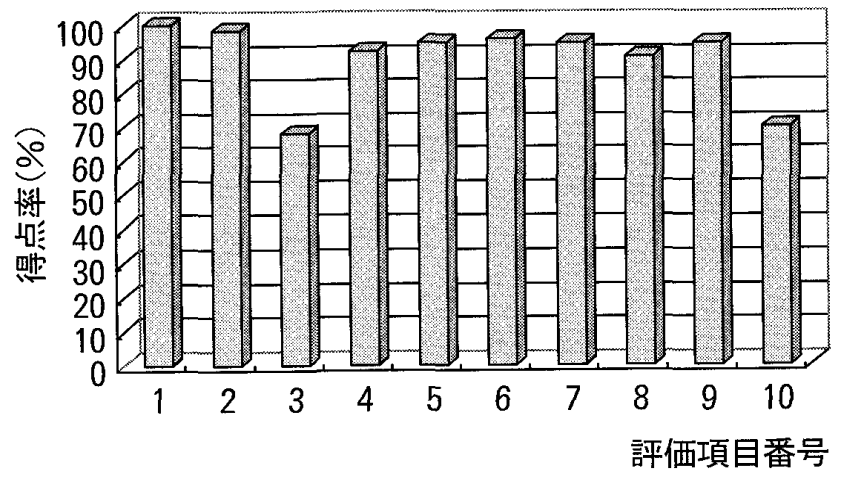

図 4-a 平成 15 年度評価項目別得点率 慢性期の初診患者の医 療面接。

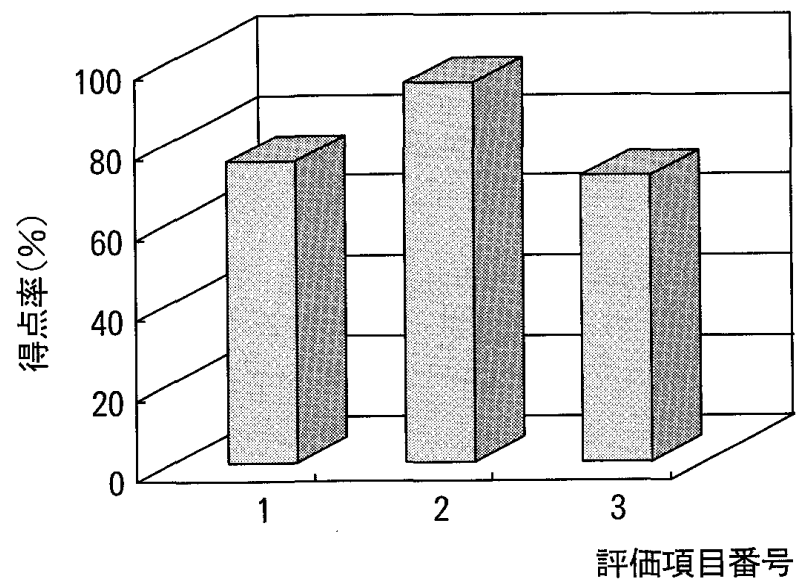

図 4-b 平成 15 年度評価項目別得点率 エックス線フィルムの 整理之読影.

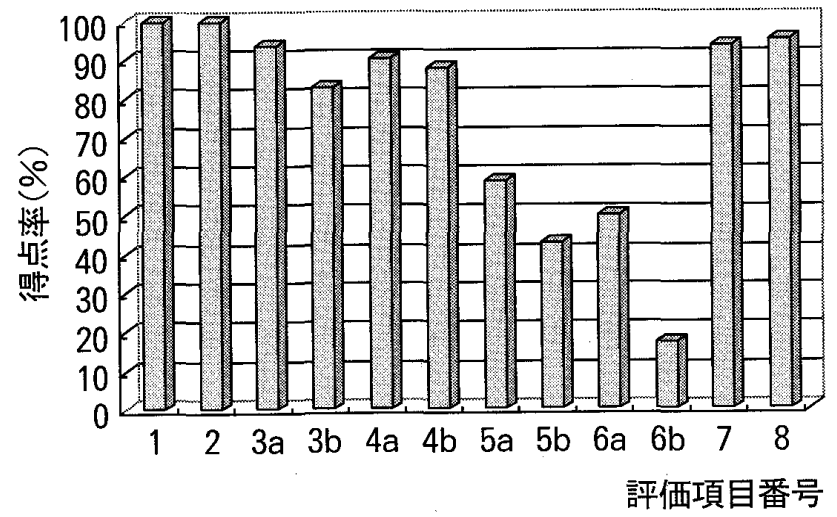

図 4-c 平成 15 年度評価項目別得点率 レジン充填.

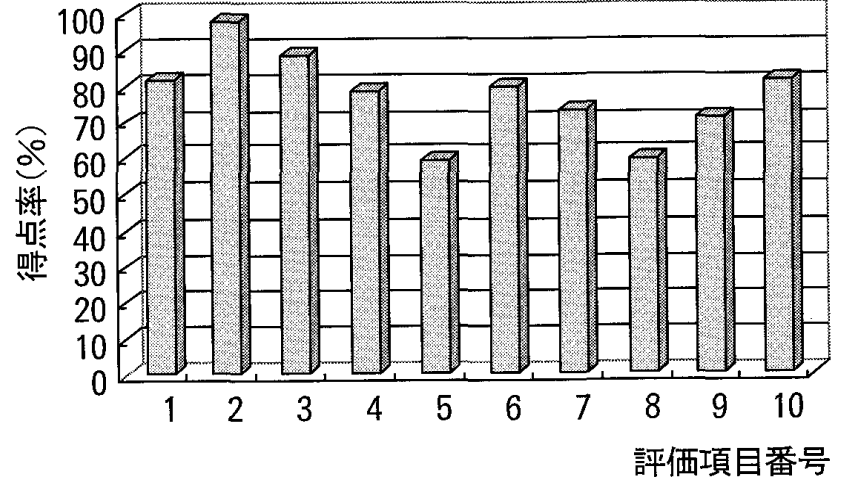

図 4-d 平成 15 年度評価項目別得点率 根管治療.

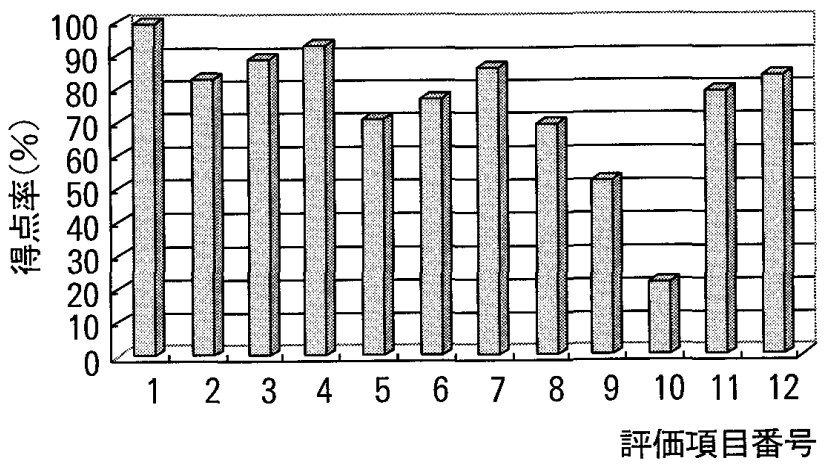

図 4-e 平成 15 年度評価項目別得点率 支台歯形成.

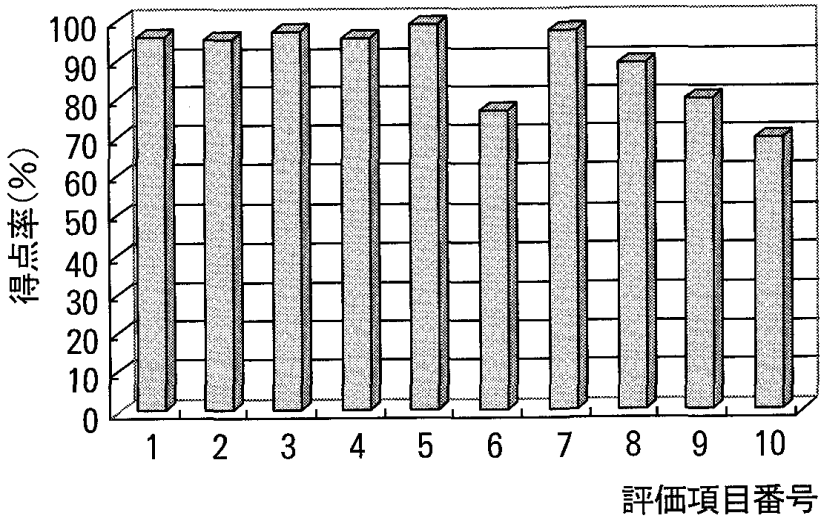

図 4-f 平成 15 年度評価項目別得点率 矯正装置の説明.

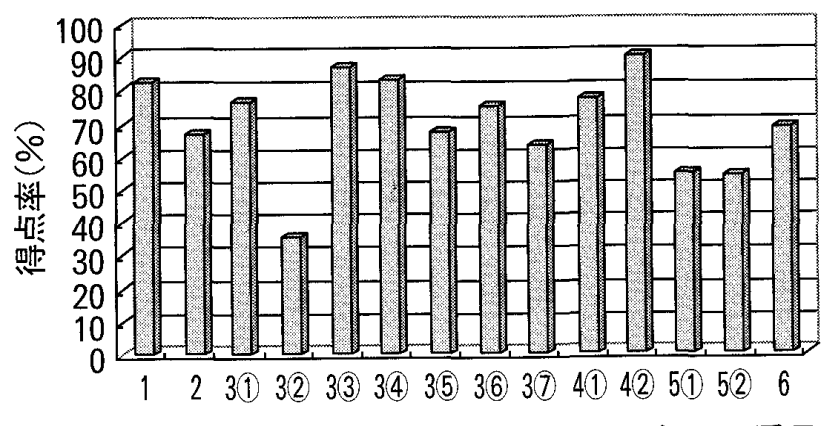

評価項目番号

図 4-g 平成 15 年度評価項目別得点率 バイタルサイン。 
表 2 得点率の低い評洒項目

\section{普通抜歯}

$4:$ 抜歯挺子の操作ができる

$5:$ 抜歯鉗子の操作ができる

ラバーダム防湿

13: シートがフレームに確実にかかっていた。

14: シートをクランプ・ウィングからはずした。

15: 隣接面にフロスを通した。

16: ラバーダムシートで，鼻孔を塞がなかった。

17: 術野を同心円上に消毒した。

ブラッシング指導

$1:$ 現状の口腔清掃状態を説明できる

$2:$ 刷掃の重要性について説明できる

概形印象採得

6 : 正確な印象が採得できる（トレーの位置が適

切, 致命的な気泡がない、トレーの露出がない)

\section{初彮患者の医療面接（慢性期）}

4: 対人空間をとることができる

$8:$ 共感的な対応ができる

10: 言い忘れの確認と要約ができる

初診患者の医療面接（慢性期）

$3:$ 対人空間をとることができる

10: 要約と言い忘れの確認ができる
エックス線フィルムのマウントと読影

1：フイルムの取り扱いができる

$3:$ 解剖学的所見の説明ができる

\section{レジン充填}

5:レジン充填 $a$ : 充填まで行えた $b$ : 充填の状態
6 : 光照射
$\mathrm{a}$ : 照射器の位置
$\mathrm{b}$ : 照射時間

根管貼薬

5 : 化学的清掃剂の正しい使用法ができる（交互洗浄の方法） 8：根管貼薬の操作ができる（綿栓が巻けた，薬液をつけた）

支台歯形成

5 : タービン保持, レストの設定など安全で適切な処置ができる 8: ガイドグルーブの形成ができる

9: 咬合面の形成ができる（適切な形態，形成量）

10：咬合関係、クリアランスを確認できる

\section{矯正装置の説明}

6 : 来院間隔と治療期間について説明できる

9 : 保護者が質問しやすい雾囲気をつくる

10 : 説明内容を確認し，同意を得ることができる

バイタルサイン

3 : 適切な血圧測定 (2)測定部位 (7)空気を抜く

5 : 血圧, 脈拍の結果 (1)血圧の測定結果 (2)脈拍の測定結果

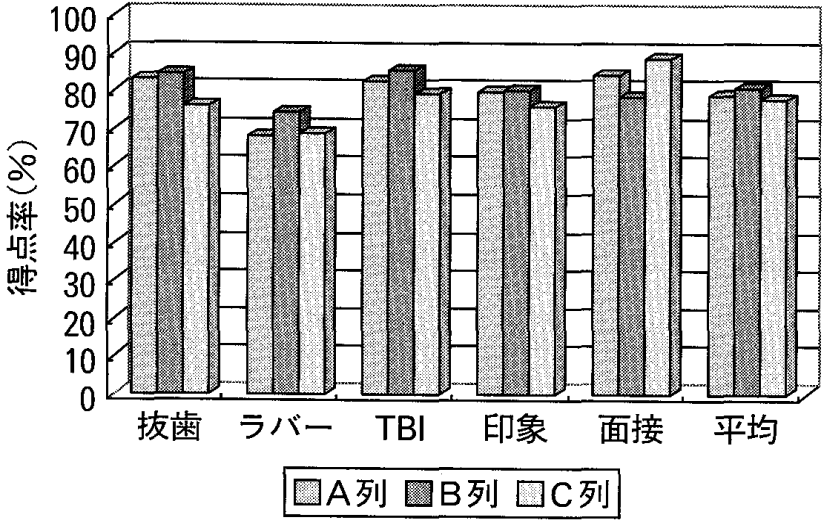

図 5-a 平成 14 年度受験会場別得点率.

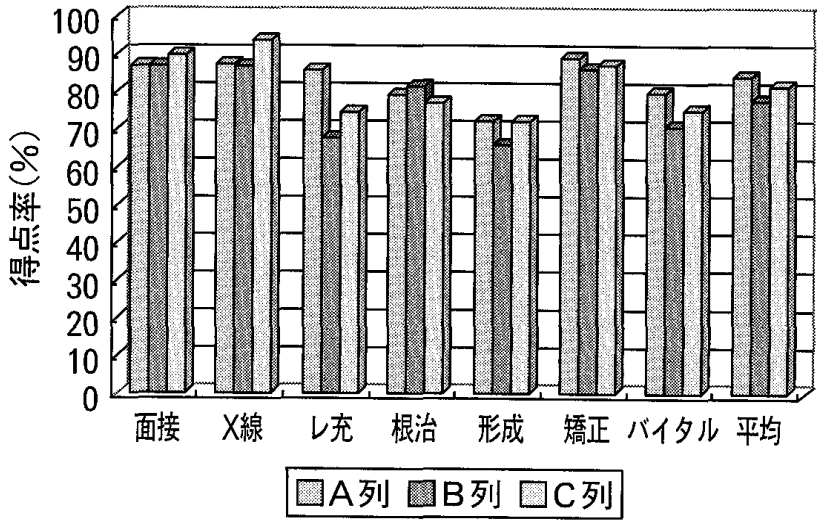

図 5-b 平成 15 年度受験会場別得点率. 
題では，平均得点率がほとんよ゙一致していた。

\section{4 ) 受験時間別得点率}

各年度における，受験時間の違いによる平均得点率を 図 6-a および図 6-b に示す。1 回目においては，受験時 間の違いによる得点差の傾向は認められなかったが，2 回目に打いては，面接・説明系課題では平均得点率に差 が認められないむのの, 診察・技能系課題において受験 時間の遅い学生ほど平均得点率が高くなる傾向がすべて の課題において認められた。

5 ）判定基準に基づく合否判定

得点率が $60 \%$ 以上で合格とした場合の，各年度にお ける，課題別不合格者数を図 7-a および図 7-b に示す. また同じ基準で合否判定した場合の，各年度における不 合格課題数別受験者数を図 8-a および図 8-b に示す．総 合では 1 回目の不合格者は 1 名, 2 回目は 0 名であっ た.

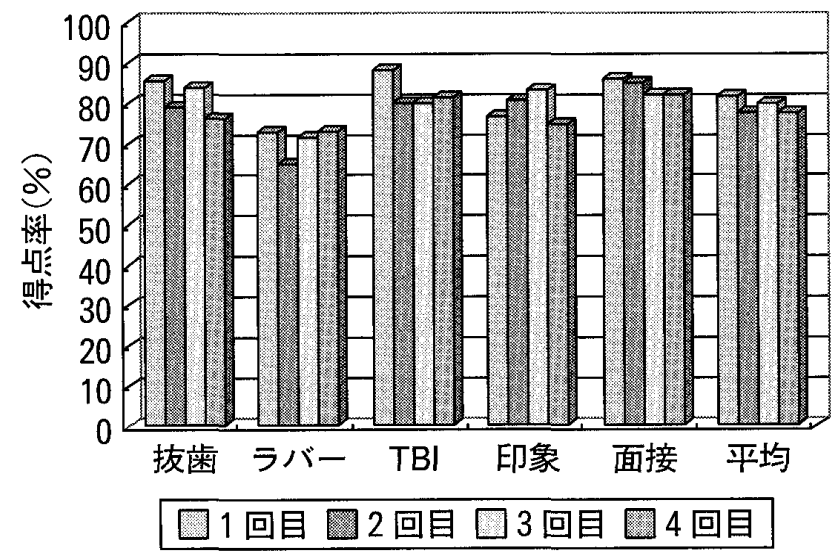

図 6-a 平成 14 年度受験時間別得点率.

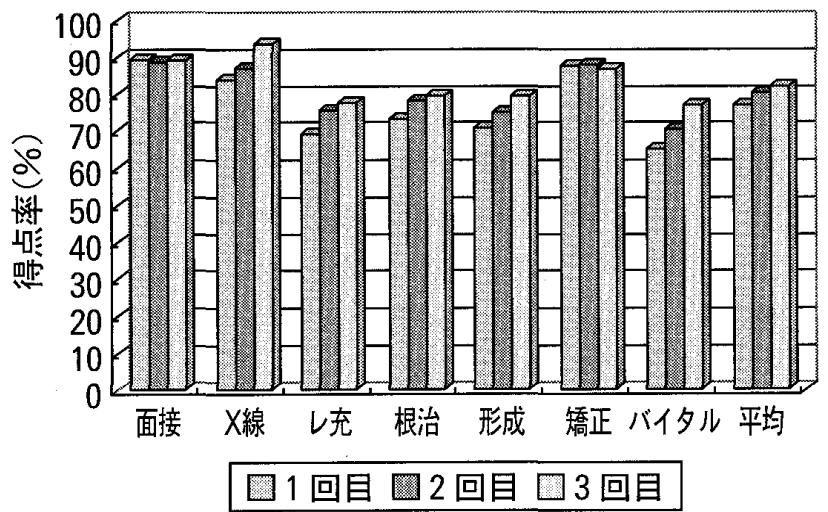

図 6-b 平成 15 年度受験時間別得点率.

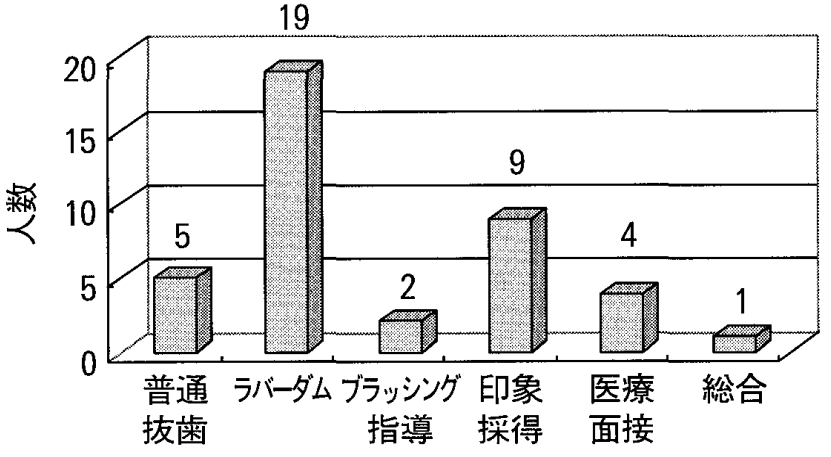

図 7-a 平成 14 年度課題別不合格者数.

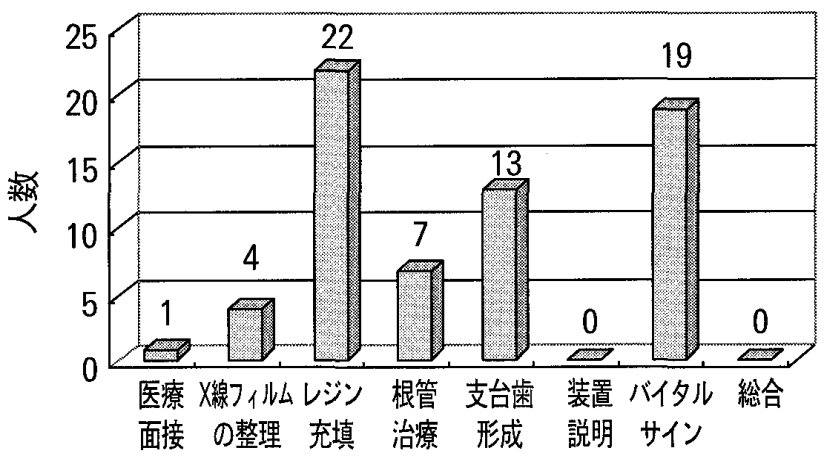

図 7-b 平成 15 年度課題別不合格者数.

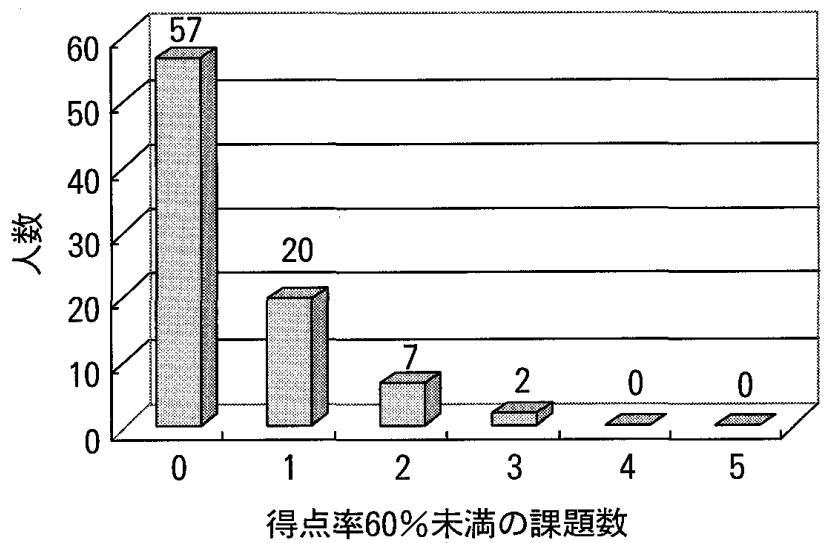

図 8-a 平成 14 年度不合格課題数別受験者数.

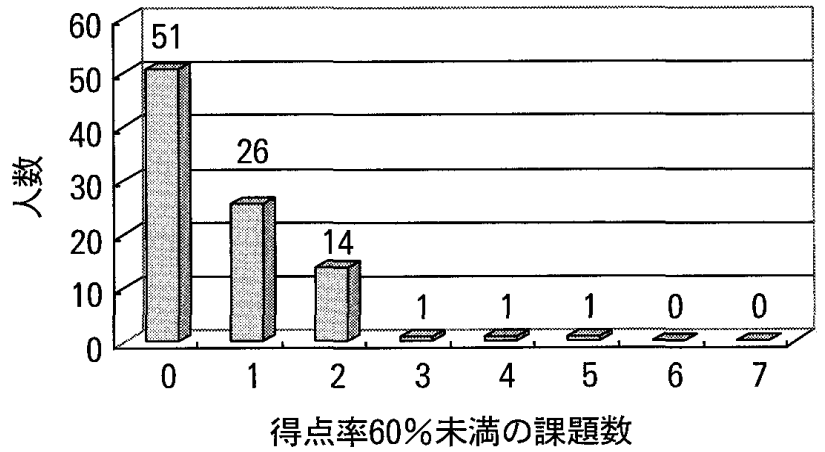

図 8-b 平成 15 年度不合格課題数別受験者数。 


\section{考察}

1. 実施方法㧍よび内容

1) 受験者㧍よび運営全般

1 回目は 86 名, 2 回目は 94 名の 5 年次生が OSCE を 経験した。トライアルであり，かつ土曜日の実施という こともあったが, 病欠（3名と 5 名）を除きほとんどの 学生の参加が得られた。これは OSCE に対する学生の関 心の高さを反映しており，多くの学生の臨床実習に対す る学習意欲の向上につながったと思われた。 また， 2 回 目トライアルでは, 4 年次生と 3 年次生を受験生の誘導 と模擬患者として参加させた。自主的な参加ということ ああり, 参加者の反応は良好で, 低学年における学習意 欲向上を図る上でのひとつの有効な手段になると思われ た。本試験に下級生を参加させることは, 試験の公正性 からみて問題があると思われるが，Early Exposure の ひとつとして，モチベーション向上と教育効果が得られ ると思われる。

2 回のトライアルには, 多くの教員が参加し, 模擬患 者や運営担当として歯科衛生士や事務職員が参加した. このトライアルの経験によって, 多くの教員が OSCE の 意義を理解し，カリキュラムの改善が必要であることを 認識しており, 効果的な FD (Faculty of Development）になったと思われる，また，OSCEを実施する上 では, アナウンス, 集計業務, 受験生管理, 受験生誘導 などの業務は，非常に単調でハードな業務であることす わかった. 今後の本学における OSCE の円滑な運営を行 うためには，業務の内容を十分配慮した人員配置を行う ことが大切であると思われた。

2) 課題, 評価シート, 評価マニュアルの作成

2 回のトライアルにおいては, 課題, 評価シート, 評 価マニュアルは関連講座が共同で作成した，本学の教 育・指導内容を加味した評価シートが作成できたと思わ れる.また，これらの作業を複数の関連講座が担当する ことによって, 同一の学習内容にも関わらず, 別々に教 授されてきた内容を，共同で確認・検討できたことは， 大変意義深いことであった.

\section{3 ) 試験環境}

OSCE 実施に当たっては，資源，特に試験環境の整備 が問題となる，本学においては，OSCE 実行委員会の立 ち上げから 2 度のトライアルを通して, 様々な検討を 行ってきた. 結果, 本学附属病院の外来診療室を OSCE 試験場として活用することで, 本格実施に対応できる施 設として利用できることが確認された。

\section{2。試験結果}

1 ) 課題別平均得点率之総平均得点率

全課題の総平均得点率は, 1 回目が $79.4 \pm 8.0 \%, 2$ 回 目が $80.4 \pm 6.4 \%$ \%あり，良好な結果といえる。課題別に みると, 一部の技能系課題で得点率が低く, 面接説明系 課題は得点率が高かった。田口ら $(2003)^{1)}$ は, 臨床研修 医に対する OSCE 課題の到達度の推移を検討し, 到達率 は, 認知領域 (知識), 情意領域 (態度), 精神運動領域 （技能）の順に低くなると報告しており，我々の結果と 一致している，今回の 2 回のトライアルでは, 試験課題 の教育状況を担当者が検討し，場合によっては再教育を 実施した。本学のカリキュラムにはない医療面接技法に ついては，特別授業を委員会主催で害施した。また 1 回 目は試験課題を事前に公表している。このような背景に あっても技能系課題で得点が低いことから，技能の習得 には教育効果が現れにくいことを考慮して，特に効果的 な教育カリキュラムによる指導が必要之思われる，加え て, 認知 $\cdot$ 精神運動領域課題においては, 反復教育の効 果が現れやすいという報告ああり"，到達度の低い学生 への再指導や反復指導屯必要加むしれない，また，教育 から実施までの期間つまり技術の保持性も問題であるこ とも考えれば，反復指導を考慮することはさらに必要で ある。

2) 各課題に扮ける各項目の得点

各課題については，それぞれスコアの低い項目が認め られた. 2 回のトライアルに扔ける課題招よび評価シー ト之評価マニュアルは, 委員が本学の教育水準に合わせ て作成したものである，従って，教育した内容を評価項 目として設定し，難易度は調整されていると考えられ る. 小川ら $(2002)^{2)}$ は, 臨床研修におけるへルスコミュ ニケーション能力教育に関する研究において，1回目か ら得点の高い項目は, 「挨拶, 患者誘導, アイコンコンタ クト，言葉遣い」で，指導することによって到達率の高 くなる項目は,「名前の確認, 言葉かけ, 体位の確認, 対人空間, 質問法」であり,「共感的態度, 訴えの確認, 言い忘れの確認」は教育効果が現れにくい項目であると 報告している。我々の 2 回の医療面接においても，同様 の項目において得点率が低かった。 また, 相澤ら $(2003)^{3)}$ は，OSCEによる評価の妥当性に関して検討 し, 認知領域や精神運動領域では評価項目についての一 致度は高く, 情意領域で低く, 評価基準があいまいなも のは一致度が低いと報告している。その中で医療面接を みると，「適切な身だしなみ」「名前の確認」「相手を配慮 した言葉遣い」「開かれた質問」「共感的な対応」「言い忘 
れの確認」などの一致度が低いという結果になってお り，評価基準のキャリブレーションの問題も含むと報告 している．本研究では分析しなかったが，本大学での OSCEにおいても同様の問題が存在する可能性があり, 今後の検討が必要である.

各課題において得点率の低い項目について，その原因 を推定することは容易ではないが，教育者は項目別に分 析を加え, 今後の教育や指導にフィードバックすること が大切である。

\section{3 ）試験会場が得点に与える影響}

OSCE を実施するにあたっては，試験としての公正 性，公平性を確保しなければならない。そのために試験 環境の統一は重要である.2回のトライアルにおける試 験会場別課題別平均得点率をみると, 診察·技能系課題 であるレジン充填, 支台歯形成, バイタルサインに掞い て B 列 (義歯科) での得点率が若干低い傾向が認められ た屯のの, 場所による試験への影響についてはほとんど ないことが確認できた。

\section{4 ）試験時間の影響之問題漏洩の影響}

OSCE は，その妥当性, 信頼性, 客観性の高さから, 臨床能力の評価法として高く評価されている. OSCE は 問題の漏洩の影響が少ない試験方法であるということ と, 受験生を長時間拘束するのは肉体的に問題であると いうことから，2 回のトライアルでは，受験生は拘束せ ず，受験内容を漏洩させないよう注意して実施した。

平成 14 年度においては, 受験時間によって課題別に 平均得点率の差は認められなかった。平成 15 年度にお いては，診察·技能系課題に抢いては，受験時間の遅い 学生ほど平均得点率が高くなる傾向が認められた。一 方, 面接・説明系課題では平均得点に差は全くなかった. 他の要因む考えられるが，試験内容の漏浅による得点の 向上は否定できない，技能系課題で影響が強く，面接・ 説明系課題で影響がなかったことは特徴的である。試験 の公正性や公平性を考えると, 試験問題が漏洩するよう な状況はなくすべきであり，そのための受験生の拘束む やむを得ないと考える，また，平成 15 年度では試験課題 を明らかにしなかったことから，試験前に課題内容を知 り得たかどうかだけであ，かなり得点に影響を及ぼした のではないかと推察される。

\section{5 ）評価基準}

2 回のトライアルの結果は, 平均点でみると満足のい く結果と思われる。しかしながら，平均点は合格基準に 達していても，ある特定の課題の到達度が極めて低い場 合や，不合格課題数が多い学生がいることがわかった.
また，課題別で不合格者数にかなりのばらつきがあるこ とも明らかとなった。

OSCEの結果は, CBT の結果と合わせて, 臨床実習 前の学生評価に用いられる，特に，患者と接する態度に ついての評価は, 臨床実習を開始するにあたって重要な 評俩項目である. OSCE で評価した態度, 技能, 知識の 結果をどのように個人評価につなげていくかついての本 学における明確な基準はなく, 今後の重要な検討課題の ひとつである。ささらに，到達度の低い課題や評価項目に ついては, 課題の適正や受験生の個人差なども含めて, 総合的に分析し, 今後の本学における臨床教育方法に フィードバックする必要がある。

\section{結論}

九州歯科大学において, 5 年次生を対象に, 第 1 回 OSCEトライアル（86名）を2003年3月 15 日に, 第 2 回 OSCEトライアル (94 名) 2003 年 12 月 6 日に実施 した. 第 1 回目は 5 課題（普通抜歯, ブラッシング指導, ラバーダム防湿, 概形印象採得, 急性期の初診患者の医 療面接), 第 2 回目は 7 課題 (慢性期の初診患者の医療面 接, エックス線フィルムの整理之読影, レジン充填, 根 管治療, 支台歯形成, 矯正装置の説明, バイタルサイン)

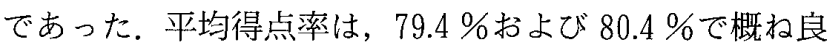
好であった．課題別にみる上，面接・説明系課題に比較 して, 技能系課題の平均得点率が低くなる傾向が認めら れた。 また技能系課題においては受験会場および受験時 間の違いによる平均得点率にやや差が認められた。

本 OSCEトライアルは多数の教職員および協力者の ご尽力により実施できたことを明記します。なお本稿の 要旨は, 第 64 回九州歯科学会総会（平成 16 年 5 月 16 日) および第 23 回日本歯科医学教育学会学術大会 (平成 16 年 7 月 2 日, 新潟市) において発表した。 またこの研 究は, 平成 16 年度九州歯科大学学長競争枠研究費で行 われた。

\section{引用文献}

1) 田口則宏, 小川哲次, 森下真行, 富士谷盛興, 吉野 宏, 谷 亮治, 伊藤良明, 田地 豪, 玉本光弘, 渡邊峰朗, 海 原康孝, 田口 明, 寶田 貫: 総合歯科医療研修に扔ける OSCE の標準化一研修前期, 中期, 後期における到達度の 推移一. 日歯教誌 $18: 239-247,2003$.

2) 小川哲次, 田口則宏, 赤川安正: 臨床研修に打けるへルス コミュニケーション能力教育一客観的臨床能力試験 (OSCE) を用いた医療面接の評価結果について一. 日歯教 
誌 17:274-282, 2002.

3 ) 相澤文恵, 岸 光男, 熊谷敦史, 石川義人, 藤沢政紀, 清 野幸男, 戸塚盛雄, 米萭正美: OSCEにおりる評価の妥当 性に抢ける評価の妥当性に関する検討一第 1 報 複数評価 者間の評価の一致度についての分析一, 日歯教誌. 19: 109-118, 2003.

4 ）俣木志朗：「モデル・コア・カリキュラムと共用試験」共用 試験 OSCE について．日歯教誌 18：57-63， 2002.

5 ）田口則宏, 小川哲次, 笹原妃佐子, 富士谷盛興, 谷 亮治, 伊藤良明, 田地 豪, 玉本光弘, 田中栄二, 石川隆義, 田 口. 明, 珼田 貫, 赤川安正: OSCE 実施に対する卒後臨 床研修医へのアンケート調查. 日歯教誌 17:290-296, 2002.

6) 田口則宏, 小川哲次, 笹原妃佐子, 富士谷盛興, 谷 亮治, 伊藤良明, 田地 豪, 玉本光弘, 田中栄二, 石川隆義, 田 口 明, 寶田 貫, 赤川安正: 総合歯科医療研修評価に打 ける OSCE の導入. 日歯教誌 17:386-394, 2002.

7 ) 水流和德, 伊藤博夫, 富田浩一, 瀬戸口尚志, 門川明彦, 川島清美, 西原一秀, 瀬戸上康子, 重田浩樹, 佐藤強志, 石神哲郎, 長岡英一: 本学歯学部における OSCEトライア ルの実施方法について. 日歯教誌 19: 160-169, 2003.
8 ）木村裕一, 宮下 元, 長谷川篤司, 渡辺治爾, 角田左武郎, 菅沼岳史，塚崎弘明，天野均，佐野司，五島衣子，岡 野友宏, 後藤延一: 臨床実習終了時に扔ける歯の基本的診 察能力を評価するための OSCE 課題. 日歯教誌 19:249258, 2004.

9 ）吉田登志子, 宮脇正一, 新井英雄, 鳥井康弘, 荒川 光, 下野 勉, 吉山昌宏, 永井教之: 客観的臨休能力試験 (OSCE) のステーション間に扔けるコミュニケーション技 能の関連性について。 日歯教誌 19:332-342, 2004.

10）田口則宏, 小川哲次: Clinical Skill Assessment としての OSCE. 日歯教誌 119:343-351, 2004.

11）村上純子, 竹中秀夫, 堀越 昶, 沢田海彦, 佐藤 貢, 大 井洋之, 村上正人, 矢内 充, 竹内 仁, 熊坂一成, 矢崎 誠治: 客観的臨床能力試験 (OSCE) における医療面接評 価の問題点一評価者の客観性をより高めるために一. 医学 教育 $32: 231-237,2001$.

12）岸光男, 相澤文恵, 大平明範, 佐藤 仁, 佐藤雅仁, 東 海林理, 福田容子, 古内秀幸, 八木正篤, 戸塚盛雄, 米満 正美：OSCE に抢ける評価の妥当性における評価の妥当性 に関する検討一第 2 報 医療面接で評価者は何を評価して いるか一. 日歯教誌 19: 119-124, 2003. 